\title{
Solitary Rectal Ulcer Syndrome: An Exceptional Entity in the Elderly
}

Safa Ourida ${ }^{1,2}$, Mariem Elleuch ${ }^{1,2}$, Ines Lamloum ${ }^{1,2}$, Salem Bouomrani 1, 2,*

${ }^{1}$ Department of Internal medicine, Military Hospital of Gabes, Gabes 6000, Tunisia.

${ }^{2}$ Sfax Faculty of Medicine, University of Sfax, Sfax 3029, Tunisia

Corresponding Author: Salem Bouomrani, Department of Internal medicine, Military Hospital of Gabes, Gabes 6000, Tunisia.

Received date: May 21, 2021; Accepted date: June 01, 2021; Published date: July 24, 2021

Citation: Ourida S., Elleuch M., Lamloum I., Bouomrani S. (2021) Solitary Rectal Ulcer Syndrome: An Exceptional Entity in the Elderly. J. Gastroenterology Pancreatology and Hepatobilary Disorders 5(4) DOI:10.31579/2641-5194/033

Copyright: () 2021, Salem Bouomrani.This is an open access article distributed under the Creative Commons Attribution License, which permits unrestricted use, distribution, and reproduction in any medium, provided the original work is properly cited.

Abstract
Solitary ulcer of the rectum or better the syndrome of solitary rectal ulcer syndrome (SRUS) is a rare benign
pathology with a prevalence estimated at $1 / 100,000$ inhabitants. It mainly affects young patients with a maximum
incidence between the third and fourth decade of life, but can be seen at any age. It remains exceptional in the
elderly with only few sporadic cases in the world literature.
We report an original case of SRUS occurring in a 70 -year-old man with no particular pathological history, who
was explored for rectal bleeding with anal pain that had been evolving for two years.
As rare as it is, this entity deserves to be known by any healthcare professional caring for elderly subjects because
can sometimes progress unfavorably with severe and even fatal complications such as massive bleeding and
perforation.
Keywords: solitary rectal ulcer, solitary rectal ulcer syndrome, elderly.

\section{Introduction}

Solitary ulcer of the rectum or better the solitary rectal ulcer syndrome (SRUS) is a rare benign pathology [1, 2]. Its prevalence has been estimated at 1/100,000 inhabitants with a slight female predominance [2, 3]. This uncommon disorder of the rectum is little known by health professionals, and very difficult to manage with no consensus on its treatment [1-3]. The typical endoscopic presentation of SRUS is the single ulcer on the anterior wall of the rectum; however other less specific and more challenging aspects may be noted such as multiple rectal ulcers, mucosal hyperemia, giant ulcers, and polypoid lesions [1-3].

The SRUS is a disease of young adults with a maximum incidence between the third and fourth decade of life [1-4]. The forms of the child and the elderly remain exceptional $[3,4]$. They pose a real diagnostic and therapeutic challenge for practitioners; particularly in the elderly where the SUSR can mimic a carcinoma of the rectum [5] and be a cause of sometimes serious digestive bleeding [6]. In addition, this syndrome significantly affects the quality of life of these patients [4-6].

We report the original observation of a solitary ulcer of the rectum occurring in a 70-year-old man.

\section{Case presentation}

A 70-year-old man, with no particular pathological history, was admitted to our department for exploration of rectal bleeding with anal pain that had been evolving for two years. The somatic examination was unremarkable. Examination of the anal margin showed anal mucous prolapse on exertion. The digital rectal examination revealed a sphincter hypotonia on voluntary contraction.

Baseline laboratory tests revealed mild normochromic normocytic anemia at $10.8 \mathrm{~g} / \mathrm{dl}$. The rest of the tests were within normal limits: leukocytes, platelets, erythrocyte sedimentation rate, C-reactive protein, serum protein electrophoresis, transaminases, creatinine, serum calcium, ionogram, glycemia, lipid parameters, and thyroid hormones.

Colonoscopy showed an isolated ulceration measuring $2 \times 3 \mathrm{~cm}$ and located $10 \mathrm{~cm}$ from the anal margin with an erythematous rim, and prolapse of the rectal mucosa. The remainder of the colonoscopy was normal. Histological examination of the biopsies taken from the ulceration showed a nonspecific inflammatory change. Surgical excision was performed under general anesthesia after anal dilation. Pathological examination of the resection piece was consistent with the diagnosis of a solitary ulcer of the rectum. No malignant cells, granulomas, or microabcesses were noted. The evolution was favorable without subsequent recurrence.

\section{Discussion}

Solitary rectal ulcer syndrome is a benign disease of the rectal mucosa that has recently been identified by Haskell \& Rovner in 1965 [7]. It results in the occurrence of a rectal syndrome associating to varying degrees: dyssynergic defecation, tenesmus, rectal pain, mucoid secretion, rectal bleeding, obstructed defecation, faecal incontinence, selfperception of anal procidentia, diarrhea, pelvic discomfort, and painful 
defecation [1-6]. However, nearly $26 \%$ of patients can remain completely asymptomatic [2-4].

It is a rare entity that mainly affects young patients but can be seen at any age $[3,4]$. It remains exceptional in the elderly with only few sporadic cases in the world literature $[8,9]$.

Its pathogenesis is still uncertain. It seems to be a complex and multifactorial problem involving prolonged straining during defecation, direct instrumentation or digital rectal trauma, chronic constipation, and rectal prolapse [1-6].

Diagnostic certainty of SRUS is based on histological examination [1-6] because clinical and endoscopic presentations can sometimes be misleading, especially for giant, circumferential, polypoid, or pseudotumoral forms simulating inflammatory bowel disease or rectocolic cancer [10-13].In addition to colon endoscopy, the exploration of SRUS must always be supplemented by the search for a disorder of the rectal statics, mainly by dynamic rectal examination: anorectal manometry, balloon expulsion test, and a defecography [2-4].

Usually considered a benign disease, SRUS can sometimes progress unfavorably with severe and even fatal complications (massive bleeding and perforation) $[14,15]$.

Therapeutic management remains debated without any consensus [16]. It schematically comprises two components: medical and surgical, and often requires a multidisciplinary team $[2-6,16]$.

Medical treatment consists of laxatives, behavioral therapy, topical treatments, sucralfate, human fibrin, biofeedback, sulfasalzine , and rehabilitation [2-6,16]. Chirurgical treatment eliminates ulceration and aims to correct rectal static disorders (rectopexy) [2-6, 16]. Argon plasma coagulation may represent a good alternative for SRUS refractory to conventional treatment [17].

\section{Conclusion}

As rare as it is, this entity deserves to be known by any healthcare professional caring for elderly subjects. It should be discussed in front of any defecation disorder, even minor. Only early and appropriate diagnosis and management can improve the prognosis of this disease, which risks compromising life in the elderly..

\section{Conflicts of interest:}

None

\section{References}

1. Torrijo Gómez I, Balciscueta Coltell Z, Sanjuan Jiménez J, Uribe Quintana N. Solitary(2018) rectal ulcer in a patient with rectal prolapse. Cir Esp.; 96(4):234.

2. Felt-Bersma (2021) RJF. Solitary rectal ulcer syndrome. Curr Opin Gastroenterol. 37(1):59-65.
3. Sadeghi A, Biglari M, Forootan M, Adibi P. (2019) Solitary Rectal Ulcer Syndrome: A Narrative Review. Middle East J Dig Dis. 11(3):129-134.

4. Forootan M, Darvishi M. Solitary (2018) rectal ulcer syndrome: A systematic review. Medicine (Baltimore).;97(18):e0565.

5. Amaechi I, Papagrigoriadis S, Hizbullah S, Ryan SM.(2010) Solitary rectal ulcer syndrome mimicking rectal neoplasm on MRI. Br J Radiol.; 83(995):e221-224.

6. Urganc N, Kalyoncu D, Usta M, Eken KG. (2014)A rare cause of severe rectal bleeding: solitary rectal ulcer syndrome. Pediatr Emerg Care.;30(10):736-738.

7. Haskell B, Rovner H. (1965) .Solitary ulcer of the rectum. Dis Colon Rectum. 8(5):333-336.

8. Van Peenen HJ, Bickerstaff LK, Callaghan JP.(1982) Solitary benign rectal ulcer in elderly women. J Iowa Med Soc.;72(12):485-487.

9. Demirci H, Ozturk K, Kantarcioglu M, Uygun A, Bagci S.(2015) Solitary Rectal Ulcer Syndrome in an Elderly Adult. J Am Geriatr Soc.;63(6):1270-1271.

10. da Fonseca LM, Souza Fde L, Arantes V,(2010) da Silva RG. Giant refractory solitary rectal ulcer syndrome treated with topical sucralfate. Int J Colorectal Dis.;25(8):1025-1026.

11. Yagnik VD. (2011) Massive rectal bleeding: rare presentation of circumferential solitary rectal ulcer syndrome. Saudi J Gastroenterol.;17(4):298.

12. Saadah OI, Al-Hubayshi MS, Ghanem AT.(2010) Solitary rectal ulcer syndrome presenting as polypoid mass lesions in a young girl. World J Gastrointest Oncol.;2(8):332-334.

13. Ingle SB, Patle YG, Murdeshwar HG, Hinge Ingle CR. (2012) An unusual case of solitary rectal ulcer syndrome mimicking inflammatory bowel disease and malignancy. Arab J Gastroenterol.;13(2):102.

14. Kato K, Nagase A, Iwasaki Y, Taniguchi M. (2014) Massive bleeding from visible vessels within a solitary rectal ulcer. Surgery. 155(5):956-957.

15. Fedakar R, Akan O, Eren B, Türkmen N, Cetin S. (2014) Death due to perforation of solitary rectal ulcer: case report. Soud Lek.;59(2):14-16.

16. Gouriou C, Chambaz M, Ropert A, Bouguen G, Venara A, Meurette G, et al. (2020) Management of solitary rectal ulcer syndome: Results of a french national survey: Société Nationale Française de Coloproctologie SNFCP, France. Dig Liver Dis.;52(8):885-888.

17. Shah A, Bohra S, Desai S. (2020) Argon plasma coagulation-an effective treatment for solitary rectal ulcer syndrome: A singlecenter experience from western India. Indian J Gastroenterol. doi: 10.1007/s12664-020-01089-w. [Epub ahead of print. PMID: 33175367]. 